Natasha STANOJKOVSKA-TRAJKOVSKA～UDK: 316.647.2:159.922]:616.896-053.2

Original research paper

\title{
EMPATHY AND SISTEMATISATION IN CHILDREN WITH AUTISTIC SPECTRUM OF DISORDER
}

\begin{abstract}
Autism represents pervasive development disorder which is defined as presence of abnormal or damaged development manifested prior the third year of age with characteristic form of pathological functioning in all three aspects such as social interactions, communications and with repetitive behaviour (WHO).

The essay provided an analysis of the literature which elaborates the autistic spectrum of disorder with emphasizes empathy and systematization - two important dimensions in their functioning and their social interaction.

The recommendations that comes out from the analysis of various research are pointing one element as very important and that is an intensive early treatment, application of strategies for stimulating empathy and systematization, but also the influence on the wider public for accepting children with autistic spectrum of disorder in all aspects of social living.
\end{abstract}

Keywords: AUTISTIC SPECTRUM OF DISORDER, EMPATHY, SYSTEMATISATION

\section{Introduction}

Most of the neurodevelopmental disorders are recognized by their phenotype or their genotype, but in autism there is neither a specific phenotype nor a consistent genotype. It can be diagnosed through its "behavioural" phenotype.

Difficulties that the children with autism are facing can be split into three groups which together compose the "threesome of disorders" Those are: communication, social interaction and imagination.

The following difficulties of communication are known:

lack of will for any kind of communication;

$>$ communication only when there is a need;

$>$ difficulties in speech and slow speech development;

$>$ poor nonverbal communication including eye contact, gestures, nonverbal expression, body language;

good speech development, but without social functionality - inability to start or maintain conversation, following only personal interests, not following other people talking, assumption that other people know what the child is thinking etc.; 
stereotyped speech (Hannah, 2007)

In the area of social conscious and interaction the following difficulties are appear:

$>$ lack of will for interaction with other people;

$>$ showing interest for others only when its personal needs are to be satisfied;

lack of motivation for pleasing others;

friendly, but unusual interactions;

$>$ not understanding the unwritten social rules;

> limited interaction, especially with strangers or in unknown situations;

In the area of imagination deficiency:

using toys as ordinary objects;

$>$ inability for imagination during the game or written expressions;

$>$ resisting to changes;

$>$ repetitiveness of the same games - lack of showing interest in following ideas of others;

easy memorizing of a study method without understanding it;

$>$ incapability to see the things from the other point of view;

$>$ rigid rules follow up;

$>$ limited possibility for expectation or limited ability for implementing the gained experiences;

Other difficulties in children with autism:

sensor disorders - can have increased sensitivity to different sounds, colours, textures, tastes;

sleep disorders - children with autism have a routine which is very hard to change;

eating disorder - can be very sensitive to certain textures and not willing to try new food etc.

obsession or insisting in certain routines;

$>$ difficulties in space orientation;

$>$ focus on irrelevant details;

$>$ dysfunctional movement;

$>$ cognitive disorder.

\section{Empathy - understanding and awareness of the feelings to others}

The word empathy comes from the Greek word Empatheia - Physical love, passion, bias. The examination of the literature reveals the existence of three tendencies in defining the empathy. Some authors are examining empa- 
thy as a cognitive phenomenon others as the emotional reaction and the third as a complex design which includes cognitive and emotional reactions.

The empathy can be noticed in the first days of the life of a child. The new-born that cries often, can trigger the other babies within the same room into cry. Still this cry out is not real reflection of empathy, but a response of the new-born to the unpleasant sounds. Toddlers show signs that are close to empathy. When a 2 year old child sees its mother crying it can hand her its toy or banana that it's eating, i.e. something that could comfort it when it cries. Around the 4 years of age the child starts to connect its personal feelings with others. During the school years all the way to the adolescence, empathy develops fully and becomes part of the attitude style of the young person.

According to Hoffman, 4 groups of empathy which are aligned with phases of cognitive development are:

global empathy- typical for children in the first year of their life, children often behave as though everything that happens to them also happens to other people

egocentric empathy- appears after the first year of age, the child understands itself enough as different subject compared to other children. It's capable to feel empathy and in the same time to understand when the other person is in trouble.

empathy for other people's feelings- it appears between second and third year of age and in the same time accepting other roles. The child is aware that other children have feelings that are different from its feelings and react accordingly to certain situations.

empathy to someone's life conditions-it comes later in the childhood. The child becomes aware that other children experience pleasures and discomforts not only in a direct situation, but also in the wider live circumstances and experiences.

The most efficient empathy learning is empathic parent's behaviour.

A person with autism will have difficulties in understanding other people's feelings. Their capability to compassion with others is much reduced comparing to other people. But if they are constantly reminded by the others their sense for empathy can be improved significantly. In some cases, as a result of constant practice their empathy is improving and becomes natural instead of intellectual as the empathy is never natural to persons with autism which is the case to other people. To talk with persons with autism is very similar to a journey in one way. These individuals can prefer one topic for discussion and talk a lot about it, but there will be very little sharing of ideas, thoughts and feelings compared to conversations with people who don't have autism. Almost all human beings like to talk about themselves and only themselves, which is normal and in the human nature. However, persons with autism usually do this more frequently. 
Children with autism show reduced attention to social stimulus, have small or no eye contact and anticipated movements. They very rarely show social understanding or spontaneous approaches to others, rarely imitating or responding to emotions. A person with autism behaves as though other people do not exist, he/she has short or no eye contact and doesn't respond when talked to. On his/her face there is no expression with exception when the person is angry or under stress and doesn't respond to cuddling, rather pushes away the hand who tries to cuddle him/her. Children with autism don't respond to other people's feelings: joy, sadness, smile grief or crying. Their attention is not attracted by the subject or the event that usually attracts the other people's attention in the surrounding. They don't imitate the movements and gestures and cannot predict the situation that follows (Trajkovski, 2011).

\section{Systematization}

One of most fascinating characteristics which defines autism are the repetitive and restrictive activities and interests and behavioural patterns. Examples: body swinging, putting objects in ordered line, intense connection to a specific object, rigid attachment to fixed routines, excessive talking about a certain topic etc. Individuals with autism often manifest obsessive-compulsive behaviour such as: playing with a specific toy, writing of repetitive words or numbers, putting objects in ordered line, constant talking about a certain subject and repetitive asking about specific activities (Trajkovski, 2011).

A person with autism likes predictability. Routine is their best friend. For some this repetitive characteristic can look quite bizarre. Repetitive characteristic can be jumping from one corner of a room to the other, doing it again after one, five or ten minutes and more. Another similar characteristic can be drawing the same thing repeatedly, page by page.

People who don't have autism are much more adaptive to changes in procedures. A c with typical development can be very happy if it first takes a bath or brushes its teeth and afterwards puts its pyjamas and goes to bed. . For a child with autism, this change, first bath then brushing its teeth could totally upset it. Some people believe that if they push their kid with autism to accept the problems it would be a good thing, but pushing their kid to accept changes like others do can significantly affect the quality of the live these children have.

Table 1. Clinical characteristics of autistic spectrum

\begin{tabular}{cc}
\hline Range/Process & Clinical characteristics \\
\hline Sensor & $\begin{array}{c}\text { Hypersensitivity, hyposensitivity touch avoidance, problems with } \\
\text { sensor integration, vestibular and proprioceptive problems }\end{array}$ \\
\cline { 2 - 3 } Motor skills & $\begin{array}{c}\text { Late motor development, problems with fine and gross motor skills, } \\
\text { reduced muscular tonus, difficulties with motor planning, difficulties } \\
\text { in coordination }\end{array}$ \\
&
\end{tabular}




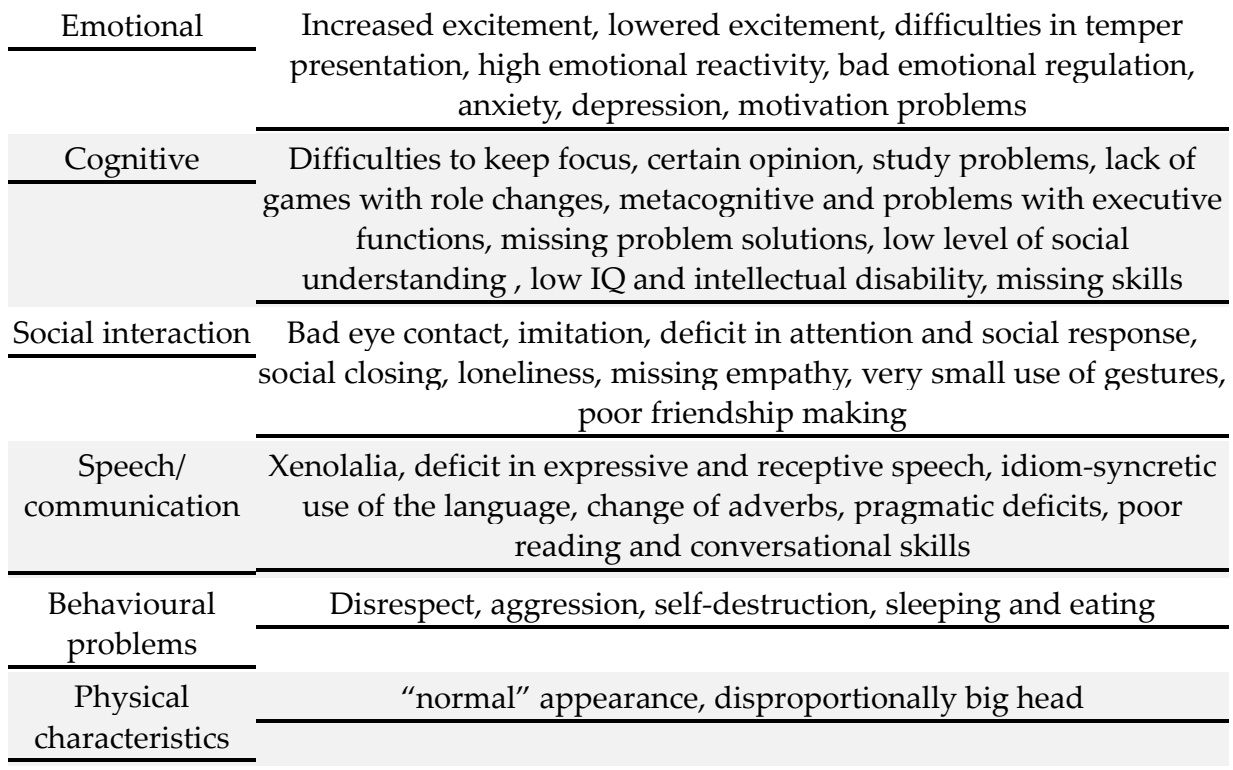

\section{Discussion}

Bonnie Auyeung and associates have done a research to discover the differences between sexes of children with autistic spectrum of disorder and children with typical development in the Questionnaire for empathy and systematization - Children's Empathy Quotient (EQ-C) and Systemizing Quotient (SQ-C). The survey was conducted among 1,256 parents of children with typical development aged 4-11 years. As anticipated, girls have shown higher results in questions for empathy, while the boys have shown higher results in questions for systematization. The same survey was conducted also among 256 parents of children with autistic spectrum of disorder, where their children have shown lower results for empathy, but higher results for systematization. In terms of sexes both groups have shown the same results.

It is accepted that men and women show significant differences in their neuroanatomy, comprehension and behaviour from early age (Baron-Cohen and associates, 2005). Baron-Cohen (2002) suggests that in line with traditional concepts on verbal and space capability, dimensions of "empathy" and "systematization" can also help in understanding human sex differences. Empathy (a desire to identify emotions and thoughts of the other and to respond to them with an appropriate emotion) is considered stronger in women, while systematization (a desire to analyse, explore and design a system) is considered generally stronger in men.

Even from the birth it is noticed that female babies show stronger advantage to social stimulus within the first $24 \mathrm{hrs}$ after the birth. Girls also have bigger eye contact after birth (Hittelman и Dickes 1979), at age of 12 months (Lutchmaya et al., 2002) and at 2 and 4 years (Podrouzek и Furrow 1988). Girls 
also show better quality in social relations when at 4 years of age (Knickmeyer et al. 2005).

Using the measurements which directly estimate the aspects of empathy, girls are better than boys when evaluating feelings and intentions of the characters in the stories and differentiating the reality of emotions (Banerjee 1997).

Studies for examination of the game are pointing out that boys show more interest in mechanical and constructive games and prefer to play with toy cars or construction sets, while girls have a bigger probability to choose a game with dolls, animals (Berenbaum и Hines 1992; Lis 1979; Servin et al. 1999; Smith and Dalglish 1977). Boys, in the same time achieve higher results in tasks which require systematization such as using guiding signs like map reading or map designing, physics (Lawson, Barron-Cohen and Scottright 2004) and math. They also show bigger space awareness capabilities and space visualization.

The autistic spectrum of disorder is characterized with disorder in social interaction and communication, along with unusual limited, repetitive, stereotypical models of behaviour, interests and activities. Two studies in the UK estimate the prevalence of autistic spectrum of disorder to be 116.1 to 10,000 and 94 to 10,000 (Baird et al., 2006; Baron-Cohen et al., 2009). This situation has neurobiological and genetical component. Also, there is a clear ratio in the incidence estimated to 4:1 for males and 10.8:1 for persons with Asperger syndrome (Gillberg et al. 2006).

In the recent study sex difference are researched in terms of empathy and systematization. The Questionnaires EQ and SQ were adapted for parental report and filled by the parents $(n=1.256)$ of children with typical development. Besides that, adapted versions of the questionnaires were completed by parents $(n=265)$ of children with autistic spectrum of disorder. Questionnaires were completed by mothers of children between 4 and 11 years of age and the research consisted of 2 groups: Group 1 was teamed with mothers of children with typical development $n=1.256$ (675 girls, 581 boys) who participated in big epidemiological study for social and communicational skills in the elementary schools in Cambridge, Great Britain (Baron-Cohen ,2009). Group 2 consisted n $=265$ (46 girls, 219 boys) of children with autistic spectrum of disorder, diagnosed by psychiatrists or adequate clinical specialist (like clinical psychologist) The subjects were mothers of children with autistic spectrum of disorder through the Centre for autism research in Cambridge and the completion of the questionnaire was done online. From the results it can be concluded that girls achieved higher results in empathy and boys in systematization. It was not recorded that there was a big difference in Evaluation of the empathy and systematization between boys and girls with autistic spectrum of disorder. Results were showing weak results to questions for empathy in children with autistic spectrum of disorder comparing with same age of children with typical development. The questionnaire can discover the poor compassions linked to autistic spectrum of disorder. Children with autistic spectrum of disorder have shown higher results on the questionnaire for the systematization in compari- 
son with comrades of their age with typical development. However, boys were more successful in this area.

\section{Conclusion and recommendations}

Based on this research we can give a conclusion that girls are better than boys in identifying emotions and dealing with them. While systematization (desire to analyse, explore, and design a system) is considered generally to be a stronger side for males. The same results were received from children with autistic spectrum of disorder.

Both, men and women know that a stereotype exists that women are more caring than men and express emotions more and maybe the answers to the questions from the research try to confirm this stereotype. Girls are raised to be more caring, empathic to other people, to understand their situation, the person's specifics and their mood while boys are raised to respect the principle of justice, which means that among children there is different emotional socialization.

The aim of this research was to put focus on autism, to raise the awareness about people who have such problems, to provide a short description of their characteristics and deeper elaboration about children with autistic spectrum of disorder.

\section{Recommendations}

- Increase awareness of local authorities and their bigger involvement in finding solutions

- Bigger support from the community

- Safer environment, social inclusion for children with autistic spectrum of disorder

- Early evaluation as benchmark for an early intervention and early inclusion

- Implemented health care, rehabilitation and continuous obligatory and intensive treatment

- Using methods and strategies for stimulating empathy and systematization in children with autistic spectrum of disorder

\section{References:}

AuYeung, B., BARON-COHEN, S., CHAPMAN, E., KNICKMEYER, R. C.,TAYLOR, K., \& HACKETT, G. (2006). Foetal testosterone and the child systemizing quotient. European Journal of Endocrinology, 155, s123-s130. doi:10.1530/eje.1.02260.

BANERJEE, M. (1997). Hidden emotions: Preschoolers' knowledge of appearance-reality and emotion display rules. Social Cognition, 15, 107 - 132. 
BARON-COHEN, S., \& WHEELWRIGHT, S. (2004). The Empathy Quotient:An investigation of adults with Asperger syndrome or high functioning autism, and normal sex differences. Journal of Autism and Developmental Disorders, 34, 163-175.

doi:10.1023/B:JADD.0000022607.19833.00.

BARON-COHEN, S., Richler, J., BisARYA, D., GuRUnATHAN, N., \& WhEELWRIGHT, S. (2003). The systemizing quotient: An investigation of adults with Asperger syndrome or high functioning autism, and normal sex differences. Philosophical Transactions of the Royal Society, 358, 361-374. doi:10.1098/rstb.2002.1206.

BHAT, S., ACHARYA, U. R., ADELI, H., ET AL. (2014). Autism: cause factors, earlydiagnosis and therapies. Rev Neurosci, 25(6), 841 - 50.

Bonnie Auyeung, Sally Wheelwright, Carrie Allison, Matthew AtKinSON, Nelum SAMARAWICKREMA, SimOn BARON-COHEN (2009). The Children's Empathy Quotient and Systemizing Quotient: Sex Differences in Typical Development and in Autism Spectrum Conditions.

HANNAH LIZ. Teaching young children with autistic spectrum disorders to learn, A practical quide for parents and staff in mainstream schools and nurseries, London, 2007.

LAWSON, J., BARON-COHEN, S., \& WHEELWRIGHT, S. (2004). Empathising and systemising in adults with and without Asperger syndrome. Journal of $\mathrm{Au}$ tism and Developmental Disorders, 34, 301-310.

Luisa C. Busch de Ahumada AND Jorge L. Ahumada (2017). Contacting the Autistic Child, Five Successful Early Psychoanalytic Interventions.

Phil Christie, Elizabeth Newson, Wendy PRevezer And Susie CHANDleR 2009. First steps in intervention with your child with autism: frameworks for communication.

ROBIN L. GABRIELS, DiNA E. HILL (2007). Growing up with autism : working with school-age children and adolescents.

ТРАЈКОВСКИ В., ВАСИЯЕВСКА К., АЈдИНСКИ Љ., СПИРОСКА М. ЕПИдемИолошки карактеристики на аутизмот во Република Македонија. Дефектолошка теорија и пракса. Скопје, 2005; 3 - 4; 25 -39.

ТРАЈКОвСКИ ВлАДИМИР Е. Аутизам и первазивни развојни нарушувань, Филозофски факултет, Скопје, 2011.

ТРАЈКОВСКИ ВЛАДИМИР Е. Медицински основи на инвалидност, Филозофски факултет, Скопје, 2008.

ЧИЧЕВСКА-ЈОВАНОВА НАТАША, РАШИЌ-ЦАНЕВСКА ОлИВЕРА. Рана интервенциија на децุа родени со фактор ризик, Филозофски факултет, Скопје, 2013. 